\title{
An investigation on the effect of organizational citizenship behavior on perceptions of service quality
}

\section{R. Ghorbani* and B Ghaempanah}

Department of Management, School of Management and Human Sciences, Tehran North Branch, Islamic Azad University (IAU), Iran

\section{CHRON I C LE A B S T RACT}

Article history:

Received 5 January 2014

Received in revised format

8 March 2014

Accepted 16 March 2014

Available online

20 March 2014

Keywords:

Citizenship Behavior

The Staff's Perceived Service

Qualities

Altruism

Generosity

Loyalty

Social Customs

\begin{abstract}
This paper studies the effect of organizational citizenship behavior on perceptions of service quality in city of Tehran, Iran in 2013. The study considers the behavior of citizens in terms of five perspectives including altruism, generosity, loyalty, social customs and courtesy. The study selects 229 regular employees of this municipality organization and applies a questionnaire designed in Likert scale. The results of Pearson correlation test as well as stepwise regression technique indicate that there were positive and meaningful relationships between organizational citizenship behavior including Altruism, $(\beta=0.445$, Sig. $=0.043)$, Social Customs, $(\beta=0.395$, Sig. $=0.000)$, Generosity $(\beta=0.299$, Sig. $=0.000)$, Loyalty $(\beta=0.193$, Sig. $=0.000)$ and Courtesy $(\beta=1.221$, Sig. $=0.000)$ and perceptions of service quality.
\end{abstract}

\section{Introduction}

For years, there have been various investigations to study the impacts of organizational citizenship behavior (OCB) on the success of various organizations. Konovsky and Organ (1996), for instance, studied whether certain dispositional factors such as agreeableness, conscientiousness could account for the relationship between contextual work attitudes and OCB by performing an investigation among 402 professional and administrative employees of a hospital and reported some strong indication that contextual work attitudes could predict most forms of OCB. Cullen et al. (2003) investigated the effects of the ethical context on organizational commitment. They hypothesized that a principled climate was positively associated with organizational commitment for professional workers but had no relationships for nonprofessional workers and their results supported this hypothesis. Baker et al. (2006) investigated the relationship between ethical behavior and organizational citizenship behaviors in studying the effects of corporate ethical values. Somers (2001) 
performed an empirical investigation on ethical codes of conduct and organizational context by examining the relationship between codes of conduct, employee behavior and organizational values. Bienstock et al. (2003) investigated the relationship between OCB and service quality. Morrison (1996) studied the role of OCB as a critical link between human resources management practices and service quality.

\section{The proposed study}

The proposed study of this paper considers one main hypothesis as follows,

Main hypothesis: Organizational citizenship behavior influences on the quality of service, positively.

The main hypothesis of this survey consists of the following five sub-hypotheses,

1. Employees' altruism influences positively on the quality of the perceived services.

2. Employees' social customs influences positively on perceived service quality.

3. Employees' generosity influences positively on perceived service quality.

4. Employees' loyalty influences positively on perceived service quality.

5. Employees' courtesy influences positively on perceived service quality.

The proposed study has been accomplished among regular employees of municipality who worked for a region located in north part of city. The sample size is calculated as follows,

$$
n=\frac{N \times z_{\alpha / 2}^{2} \times p \times q}{\varepsilon^{2} \times(N-1)+z_{\alpha / 2}^{2} \times p \times q},
$$

where $N$ is the population size, $p=1-q$ represents the yes/no categories, $z_{\alpha / 2}$ is CDF of normal distribution and finally $\varepsilon$ is the error term. Since we have $p=0.5, z_{\alpha / 2}=1.96$ and $N=630$, the number of sample size is calculated as $n=229$. The study has adopted a standard questionnaire for mearsing the effects of organizational citizenship behavior on perceived service quality (Smith et al., 1983; Organ, 1988, 1990). Fig. 1 shows details of participants' personal characteristics.

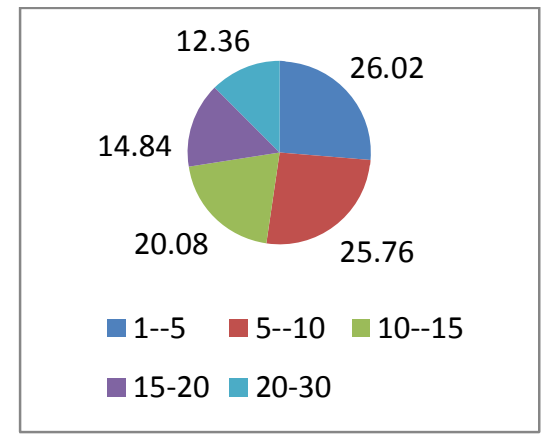

Years of job experiences

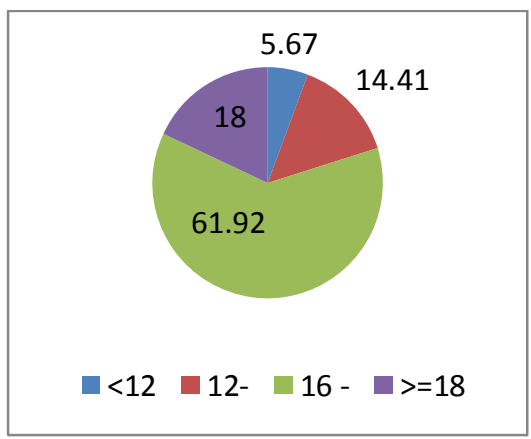

Years of educations

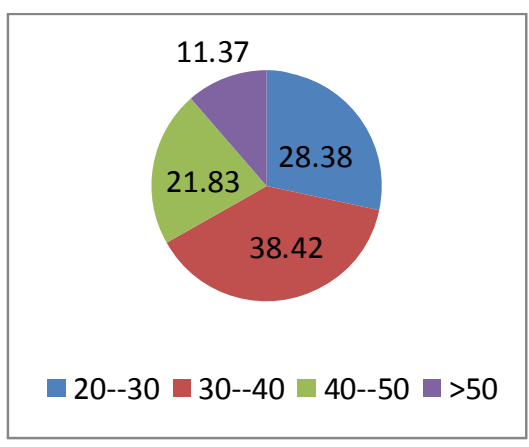

Age

Fig. 1. Personal characteristics of the participants

As we can observe from the results of Fig. 1, 74\% of the participants had at least five years of job experiences, nearly $80 \%$ of them maintained good educational background and mostly were middle aged people. In addition, about $41 \%$ of the participants were regular staff, $27 \%$ of them were operational managers, $28 \%$ of them were middle level managers and nearly $5 \%$ of the participants were top level managers. Table 1 demonstrates some basic statistics for the components of the survey. 
Table 1

The summary of some basic statistics

\begin{tabular}{lcccc}
\hline The Statistical Variables & Mean & Standard Deviation & Skewing & Kurtosis \\
\hline Perceived service quality & 2.906 & 0.6390 & -0.188 & 0.293 \\
Altruism & 3.333 & 0.6146 & -0.356 & 0.047 \\
Social Customs & 3.45 & 0.7235 & -0.645 & 0.192 \\
Generosity & 2.794 & 0.9358 & -0.020 & -1.076 \\
Loyalty & 3.433 & 0.91453 & -0.100 & -0.903 \\
Courtesy & 3.793 & 0.3256 & -0.094 & -0.935 \\
\hline
\end{tabular}

Based on the results of Table 1, courtesy maintains the highest mean followed by social customs, loyalty, altruism, perceived service quality and generosity. In order to perform statistical observation, we need to verify about the normality of variables. Table 2 demonstrates the results of KolmogorovSmirnov test.

Table 2

The summary of Kolmogorov-Smirnov

\begin{tabular}{ccc}
\hline Variables & Z Kolmogorov-Smirnov & The Level of Significance \\
\hline Perceived service quality & 1.031 & 0.238 \\
Altruism & 0.712 & 0.691 \\
Social Customs & 0.450 & 0.299 \\
Generosity & 0.741 & 0.642 \\
Loyalty & 0.777 & 0.582 \\
Courtesy & 0.777 & 0.582 \\
\hline
\end{tabular}

As we can observe from the results of Table 2, all components of the survey are normally distributed and we can use Pearson correlation as well as stepwise regression techniques to test the hypotheses of the survey.

\section{The results}

In this section, we present details of the results of Pearson correlation test as well as stepwise regression technique between organization citizenship behavior and perceived service quality.

\subsection{The results of Pearson correlation}

Table 3 demonstrates the summary of Pearson correlation test between organization citizenship behavior and perceived service quality.

\section{Table 3}

The summary of Pearson correlation test beteen organization citizenship behavior and perceived service quality

\begin{tabular}{ccc}
\hline Variables & Pearson correlation & The Level of Significance \\
\hline Altruism & 0.709 & 0.024 \\
Social Customs & 0.746 & 0.000 \\
Generosity & 0.695 & 0.001 \\
Loyalty & 0.707 & 0.000 \\
Courtesy & 0.888 & 0.033 \\
\hline
\end{tabular}

The results of Table 3 clearly indicate that there are some positive and meaningful relationships between organization citizenship behavior and perceived service quality when the level of significance is five percent. 


\subsection{Stepwise regression analysis}

To learn more about the effects of various components of organizational citizenship behavior on perceived quality, we perform stepwise regression technique and Table 4 shows details of our findings.

\section{Table 4}

The summary of stepwise regression technique

\begin{tabular}{|c|c|c|c|}
\hline Variable's Name & Coefficient & T Statistics & Sig. \\
\hline perceived quality of the services $(\mathrm{Y})$ & - & - & - \\
\hline Dependent Variables $\quad$ Intercept & 3.870 & 2.015 & 0.000 \\
\hline Altruism & $0.445^{\star}$ & 1.055 & 0.043 \\
\hline Social Customs & $0.394^{\star}$ & 1.995 & 0.003 \\
\hline Generosity & $0.299^{\star}$ & 1.615 & 0.000 \\
\hline Loyalty & $0.193^{\star}$ & 1.217 & 0.000 \\
\hline Courtesy & $1.221^{\star}$ & 1.773 & 0.000 \\
\hline
\end{tabular}

$\mathrm{R}=0.767, \mathrm{R}^{2}=0.589$, Adjusted R-Square $=0.582$, Durbin-Watson $=1.863$, F-Statistics $=1.084$

The results of Table 4 clearly indicate that all five components of organizational citizenship behavior influence positively on perceived service quality and the results are consistent with findings by Organ (1990).

\section{Conclusion}

In this paper, we have presented an empirical investigation to study the relationship between organizational citizenship behavior and perceived service quality in one Iranian municipality organizations located in city of Tehran, Iran. The study has implemented a standard questionnaire and using a random sample people applied Pearson correlation test as well as stepwise regresion technique, we have determined that all components of organizational citizenship behavior inlcuding Altruism (beta $=0.445$, Sig. $=0.043)$, Social Customs $($ beta $=0.395$, Sig. $=0.000)$, Generosity $($ beta $=$ 0.299 , Sig. $=0.000)$, Loyalty $($ beta $=0.193$, Sig. $=0.000)$ and Courtsy $($ beta $=1.221$, Sig. $=0.000)$ influence on perceived service quality, positively.

\section{References}

Baker, T. L., Hunt, T. G., \& Andrews, M. C. (2006). Promoting ethical behavior and organizational citizenship behaviors: The influence of corporate ethical values. Journal of Business Research, 59(7), 849-857.

Bienstock, C. C., DeMoranville, C. W., \& Smith, R. K. (2003). Organizational citizenship behavior and service quality. journal of services marketing, 17(4), 357-378.

Cullen, J. B., Parboteeah, K. P., \& Victor, B. (2003). The effects of ethical climates on organizational commitment: A two-study analysis. Journal of Business Ethics, 46(2), 127-141.

Konovsky, M. A., \& Organ, D. W. (1996). Dispositional and contextual determinants of organizational citizenship behavior. Journal of organizational behavior.

Morrison, E. W. (1996). Organizational citizenship behavior as a critical link between HRM practices and service quality. Human Resource Management,35(4), 493-512.

Organ, D. W. (1988). Organizational citizenship behavior: The good soldier syndrome. Lexington Books/DC Heath and Com.

Organ, D. W. (1990). The motivational basis of organizational citizenship behavior. Research in organizational behavior, 12(1), 43-72.

Smith, C. A., Organ, D. W., \& Near, J. P. (1983). Organizational citizenship behavior: Its nature and antecedents. Journal of applied psychology, 68(4), 653.

Somers, M. J. (2001). Ethical codes of conduct and organizational context: A study of the relationship between codes of conduct, employee behavior and organizational values. Journal of Business Ethics, 30(2), 185-195. 